\title{
THE CONSTITUTIONAL COURT OF ROMANIA AGAINST THE DIRECTION OF THE CONSTITUTIONAL MOMENT OF 1991
}

\author{
Assist. Prof. Răzvan Cosmin ROGHINĂ PhD \\ Lucian Blaga University of Sibiu \\ E-mail: rc.roghina@gmail.com
}

(Received October 2017; Accepted November 2017)

\begin{abstract}
The year 1991, the year when the current Romanian fundamental law came in to force, designed a constitutional moment built on profound political and societal emotions. These emotions pushed the Constituent Assembly in search of an answer, in the form of a solution, to the question „What do we not want?" The answer was: "An authoritarian president / chief of state!" Consequently, the position of the head of state in the political scaffolding received an increased attention. Unlike the Communist president, who exercised great powers, the new president was thought and designed antagonistic to his predecessor. He was reduced to a role of a simple mediator. However, more than 20 years after the fall of the communist regime, the "traditional" authoritarian personality of the president transcended - of course, not as pronounced as in the communist era - the finality of the presidential role and of the presidential attributions stated in the Constitution. As we shall see, the "player president" emerged and got confirmed by the Romanian Constitutional Court against the desideratum of the constitutional moment of 1991.

Keywords: Aversive Constitutionalism, Romanian Semi - Presidentialism, Romanian Constitutional Court, Romanian President, Constitutional Transplant.
\end{abstract}

\section{The constitutional moment of 1991 . The aims of the constituent assembly}

It is difficult to discuss an organic evolution of the Romanian constitutionalism, starting with the nineteenth century and culminating with the present, especially in a related manner. The Romanian constitutional background has undergone different constitutional practices in its history. Thus, it is troublesome to find a clear and an objective reality of the Romanian constitutionalism through a theoretical equivalence between written law and law in action.

The first written Constitution of Romania (1866) was adopted not only to give an answer to the necessity of legitimating the young Romanian national unitary state in an international geopolitical context, but also to give a reply to the authoritarian regime of A. I. Cuza. Thus, the Constituent of 1866 considered, among other problematics, an answer to the question: what do we not want? And the answer was: yet another political regime dominated by an authoritative head of state (Domn)!

The constitutional praxis that followed the constitutional moment of 1866 deviated from the functional mechanisms specific to the dualist parliamentary regime. It has come to transgress them so much that the political regime transplanted from the 
Belgian Constitution of 1831, instead of evolving towards the variant of a monistic parliamentarism, has turned into a kind of limited (constitutional) monarchy/ authoritarian constitutional monarchy / "Administrative monarchy" / "governmental regime" [1]. As a determinant reason, we can discuss the inability of the political class of that time to give a solid and consistent reply to Carol I's provoked [2] and challenging authoritarianism.

The Romanian societal and political emotions of 1866, the lack of experience in the field of constitutional creation or engineering and the inability of the Romanian political class to rationalize and truly understand the internal mechanisms and accomplishments of the massive constitutional object transplanted (almost an entire foreign fundamental law), made the effects of the Constitution unpredictable especially through the prism of the incomplete rules of the copied dualist parliamentary regime. Unconsciously granting Carol I the power of an absolute veto, leaving behind the solution of the suspensive veto [3], along with the power leverage of the right to dissolve the parliament, allowed the reactivation of the authoritarian reign in the "head of state" account.

Similarly, the year 1991, the year of the adoption of the current fundamental law (revised in 2003), designed a constitutional moment built on emotions. These emotions pushed the Constituent Assembly in search of an answer, in the form of a solution, to the question "What do we not want?" As we shall see, the answer of 1991 can be confused with that of 1866.

The Constituent Assembly, without ignoring the necessity of guaranteeing and protecting citizens' rights and freedoms - profoundly disregarded by the communist regime through the symbolism of a head of state endowed with full decision-power over the people) -, consciously chose to depart from the option of a presidential political regime and rationally limited its alternatives to a parliamentary regime or a semi-presidential regime.

The distribution of power in the reborn Romanian state, through the principle of separation of powers and through the development of a system of checks and balances, claimed as a starting point the head of state (president) institution. Therefore, the question What do we not want? received a clear answer: an authoritarian president/"head of state". As a consequence, the position of the president in the political scaffolding was heightened by a hypothetical comparison between the unwanted communist president and the desired post-communist president, in order to eliminate the possibilities of state power personalization [4]. In particular, the Communist president, endowed with exorbitant powers through the 1965 Constitution and through extraconstitutional political practices, had to be an anti-model for the post-communist president [5].

The indirect election of the Communist President by the Grand National Assembly, through electoral mimetic, created a head of state without any legitimacy stemming 
from a real agreement set by the people. Moreover, this kind of fabricated election generated an alienated president from genuine political constraints caused by the logic of the relationship between the political power beholder, which is the sovereign people, and the state power practitioners. Thus, the solution found in 1991 was the direct election of the president, in order to outline the possibility of subjecting the president to political constraints directed to the sovereignty of the people and, of course, to the fundamental law. This goal also illustrated a revolutionary desideratum expressed by the National Salvation Front in its first constitutional acts [6]. However, this circumstance, the direct election of the president, allowed the post-communist president to practice, in addition to the political exercise set by the mechanisms of the political regime prescribed by the Constitution, power counterweights before the parliament and the Government. As a consequence, a rivalry of legitimacy has developed, although the fundamental law establishes a clear hierarchy in this respect through article 61.

After setting up the election of the President, the Constituent Assembly remained focused on the solutions required for the establishment of the political regime. The lack of internal experience (in terms of constitutional creation or defining political regimes through organic regulatory acts) pushed the Constitution towards the modalities of constitutional transplant [7]. Therefore, attention was directed to those models proved accessible to the Romanian system (transplant bias [8]) and which were prestigious in the field of democracy - a desideratum pursued with enthusiasm by the Romanian society. That is why the French legal system, with its semi-presidential regime [9], had to be a landmark.

However, unlike in 1866, the constitutional moment of 1991 did not translate an unconscious [10] and irrational [11] constitutional transplant / constitutional mimetic exercise, whereas the Romanian president was consciously set aside from the French president model, charged with an important role in the government agenda. It is true, this result was, in a great part, a consequence of the Communist regime reminiscences, all gathered in the presidential institution phobia. But, even though the post-communist president was the result of a constitutionalism of aversion [12], the fear of another state power personalization generated rational and conscious references to what was to happen in the system of powers - the system of checks and balances.

Consequently, the post-communist president was endowed with limited attributions in number and weight. And not only so, they were largely conditioned by the agreement or approval of other state authorities, e.g. from the parliament.

The Constitution of Romania, in article 80, establishes a triple role for the president. That of a state representative (i), that of a guarantor of national independence and territorial integrity (ii) and that of a guardian of the Constitution (iii). This triple role was set by the constitutional text through the prism of a 
mediator mission. This fact, in correlation with other constitutional norms, discloses the intentions of the founding fathers not to set up an active president in the governance agenda of the public authorities. The President of Romania, according to the same art. 80, ensures the proper functioning of the public authorities. This constitutional article does not give the President the opportunity to design public authorities restructuring, even if he would promote his ideas based on the belief that some changes would make the public authorities work better. The presidential attitude required by the constitutional text is limited to watching, so to observe whether the public authorities operate in a constitutional and legislative way. Thus, he may not interfere when they work as such.

Article 84 (1) provides the incompatibility of the president office with any political party membership. The reasoning behind this provision is to objectively outline the mediator role of the president and to point out that he is not owed and should not rally, under the label of a "player president" or under a political badge derived from his former party position (leader or simple member), in favor of or against any political program of governance.

The revolutionary moment of 1989 and the constitutional moment of 1991 have clearly translated a political desire to take the head of state out of the active distribution and manifestation of state power. For this reason, the Constitution provides the Government with an almost complete institutional autonomy towards the president, being exclusively passed into the political control of the Parliament (art. 109 (1)]. However, there have been situations in which the Government's parliamentary accountability has been de facto overthrown during political context of consolidated majority government [13], namely the situation where the president and the parliamentary majority belonged to the same party. Under such political circumstances, the president's authoritarian personality overran the limits of article 84 (1) and highlighted the "player president".

In the light of the above, we may also consider emphasizing the powers of the president in the executive branch, more precisely in relation with the Government, in order to illustrate the intention of the Constitutional Assembly not to offer the head of state institutional possibilities to influence the governance conduct. Unlike the French President who appoints the Prime Minister, the Romanian President has been limited to nominating the candidate for this position, following the parliamentary rules. In addition, only in exceptional circumstances or at the invitation of the Prime Minister may the President participate in the Government meetings, in which case he presides, but without the right to vote. Also, the president does not countersign the government's normative acts.

An assurance against the President's authoritarian possibilities has been found by the Constituent Assembly in a presidential political responsibility (art. 95), even though the president is not effectively integrated into the act of governance. This 


\section{JOURNAL OF LEGAL STUDIES}

"Vasile Goldiș" Western University of Arad

Roghină R.C. (2017)

The Constitutional Court of Romania against the direction of the constitutional moment of 1991

issue clearly shows the fear of having a president who may do more than it was politically and constitutionally designed. That is why the president institution has been built primarily through the coordinates of a mediator. This aim also results from the fact that the dissolution of the parliament was not left in the Constitution as a presidential power leverage to judge or solve political blockages - which would have placed him in the role of a political arbitrator -, but rather as a tool that contours his role as a consensus producer (mediator).

However, when we talk about the consultative referendum, the political neutrality of the president is not clearly stated in article 90 . But this is just an effect of a solo, limited or decontextualized interpretation of article 90. Everything becomes clear when we try to understand the mentioned article through the lenses of a teleological interpretation of the fundamental law or, better said, through all the constitutional rules which were set for the political regime qualification and for the checks and balances system, per se. The Romanian Constitutional Court, instead of doing so, absolutized through its judgments the right of the president to freely choose the object of the referendum, along with the liberty of not having clear temporal limits [14]. By ignoring the teleological reading of the fundamental law and by applying the principle of constitutional loyalty in a differentiated way [15], the Romanian Constitutional Court created an extraconstitutional power lever in the presidential account. A great risk of power personalization was created through the constitutional justice. This is why we say that the Constitutional Court of Romania is, paradoxically, against the direction of the constitutional moment of 1991.

The presidential political neutrality, so desirable in the head of state political agenda, in relation with the societal emotions of 1991 and in accordance with the logic of the constitutional text, is also highlighted by the fact that the postcommunist president lacks legislative initiative, despite the fact that the Constitutional Court of Romania created the absolute presidential right to define what are the issues of national interest. Therefore, we cannot ignore the constitutional paradox of a president that solely can decide which issues are of national interest and can be an object of a consultative referendum, but cannot start a legislative debate on a matter of national interest!? [16] It is clear for us that, despite the CCR's judgment, article 90 does not set an absolute right in the President account.

Even if the President does not have the right of legislative initiative, he may initiate, based on the Government's proposal, a constitutional revision procedure. However, it is a conditioned initiative that does not allow the president to build his own will on the issues raised in the revision draft, having in mind the logic of the political system designed by the fundamental law through the prism of the role and attributions of each authority in the mechanism and finality of the checks and 
balances system. Nevertheless, the Constitutional Court has given the President, as we shall see, the possibility of canceling the government's volitional conditioning. In a semi-presidential regime, apparently not fully understood with its risks in 1991, the lack of a coherent constitutional opposition from the parliament towards the president's possible unconstitutional authority, the absence of a civil society capable to impose moral barriers to possible excesses of power, the failure to consolidate an independent judiciary and a non-apolitical Constitutional Court inevitably leads to a fall in authoritarianism.

Taking in to account the up mentioned aspects, we intend to observe how the CCR, through its jurisprudence, empowered the president on certain political power issues, widening, thus, his political autonomy and, in a counter clock manner, diminishing his political accountability.

\section{The presidentialization of the political framework through constitutional justice. The Constitutional Court of Romania vs the Constituent Assembly of 1991}

The place, role and attributions of the president must be distinguished through the prism of the constitutional teleological prescriptions from 1991 and understood through the same lenses when we read and try to interpret the Constitution 26 years later. By doing so we can project the constitutionally aimed semi-presidential regime, which, in 1991, was pre-oscillated towards parliamentarism. However, many years after the fall of communism, a new degree of power personalization through the presidential institution is noticed, having as a starting point its concurrent legitimacy with the parliament, as well as a pro-presidential constitutional jurisprudence.

Therefore, we will briefly present a series of RCC's Advisory Opinions and Decisions that highlights the above-mentioned aspects, namely the presidentialisation of the political regime against the established constitutional coordinates, which, in 1991, were very clear put in sync with the Romanian society repulse towards the - traditional (we may add) - authoritarian head of state.

In the Advisory Opinion on the President's Suspension (No. 1/2007) [17], the RCC overshadows the President's obligation to maintain political neutrality (constitutionally prescribed!) during his mandate of representing all the Romanians, and thus not only those who supported his election, based on the political color that he once had. By doing the opposite, it would mean that the president is not acting as a mediator and, as a risk; his political conduct may cause maladministration of the public authorities. The Court defined what constitutes serious violations of the Constitution, namely what does the collocation - serious offences - used by art. 95 of the fundamental law mean. 
The Court notes that serious offences upon the constitutional provisions may be considered the decision-making acts or the avoidance of compulsory decision making acts, by which the President of Romania would impede the functioning of public authorities, suppress or restrict citizens' rights and freedoms, disturb the constitutional order or would pursue change to the constitutional order, or other acts of the same nature that would have or might have similar effects.

Although the RCC expressed in the preamble of its considerations that, in theory, any constitutional norm breached by the president could mean a serious constitutional offence, given the subject of the violation, the final interpretation of the Court, on the interested collocation, received an extrapolated and diluted approach, which practically broadened the political possibilities of the president in opposition to the system of checks and balances established by the fundamental law.

... the attitude and opinions imputed to the President of Romania cannot be characterized as violations of the Constitution, given that - regarding the President's relationship with political parties - Article 84 of the fundamental law stipulates that he cannot be a member of a political party, but it is not forbidden to keep in touch with the party that supported him in elections or with other political parties [18].

Moreover, the Court erroneously stated that the President's immunity for political opinions is absolute, irrespective if we differentiate between legal liability or political accountability. In such a course of constitutional interpretations, one may viciously consider that the acts undertaken by the president in the exercise of his role as a mediator, which is manifested exclusively through political acts, cannot be engaged in a political responsibility. This would cancel out the logic of the president's political responsibility for transgressing the Constitution.

Regarding the attitude and expressions of Mr. Traian Băsescu addressed to some public figures, Article 84 paragraph (2) of the Constitution stipulates that the President of Romania enjoys immunity under the conditions of art.72 paragraph (1), i.e. for the political opinions expressed in the mandate exercise. In relation to the political purpose pursued, the President's manifestations to which the authors of the proposal for suspension refer, can be characterized as political opinions and protected by the immunity provided by the text quoted in the Constitution.

For us it is clear that the President, by alienating his mediator role through political declarations -which inevitably lead to political effects -, seriously violates the Constitution, because he is no longer fulfilling the role dictated by the fundamental law. Such political attitudes do not fit, as we mentioned, into his role as a mediator who must oversee upon the proper functioning of state authorities. He alienates, above all, his role as a guarantor of the Constitution, since the effects of his 
$\overline{\text { political declarations can destabilize the political scene and generate institutional }}$ bottlenecks. That is why his political responsibility becomes operational as a consequence and as a sanction.

In Decision 284/2014 [19], judging the obvious abandonment of the presidential mediator role, the RCC concluded that the president in office may be involved in a political party's electoral campaign, wearing shirts, taking promotional pictures and sending public support messages in this regard!? The Court has been referred to this issue in the arbitration of an institutional conflict between the President and the Government. The later argued that the President, through his active involvement in the electoral campaign, tangled the organization of impartial and fair elections, since he left his political neutrality required by the fundamental law. The Constitutional Court avoided the need to assess the constitutionality of the President's electoral involvement, although in a rule of law state, when an authority declares itself not competent on certain issues, it must indicate the competent authority. In this case, who could have been competent to evaluate the mediator role of the president and competent to resolve the constitutional conflict derived from the act of disrespecting the respective constitutional role?! The question is, of course, a rhetorical one.

The prohibitions provided by Article 84 (1) of the Constitution, according to which, during the term of office, the President of Romania cannot be a member of a party and cannot fulfill any other public or private function, do not exclude the possibility of further expressing political opinions, commitments and goals outlined in his electoral program or to militate for their achievement, respecting constitutional prerogatives. (...) Moreover, the function of mediation between the powers of the state, as well as between state and society, provided by the second thesis of Article 80 paragraph (2) of the Constitution, imposes impartiality in the account of the President of Romania, but does not exclude the possibility of expressing his opinion regarding the best way to resolve divergences and does not confer him the status of a political competitor.

Subsequently, the Court returned to the older confusion of the President's immunity considering political responsibility.

Moreover, in terms of the limits of the right to freedom of expression, the fundamental law provides in Article 72 paragraph (1), in a marginal title, "Parliamentary immunity", according to which "Deputies and senators cannot be held liable for the votes or for the political opinions expressed in the exercise of the mandate. In accordance with the provisions of Article 84 (2) of the Constitution, "The President of Romania shall enjoy immunity. The provisions of Article 72 (1) shall apply accordingly." In analyzing the legal significance of the immunity institution, the Court notes that this is a constitutional guarantee, a measure of legal protection of the mandate, which is intended to ensure the independence of the 
mandate holder from any external pressure or abuse. The guarantee provided in Article 72 (1) of the Constitution encourages the holder of the mandate to take an active role in the political life of society by removing its legal responsibility for the political opinions expressed in the exercise of the public dignity function. However, the holder of the mandate remains liable, according to the law, for all the acts and deeds committed during the period in which he exercised the public office and which are not related to political votes or opinions.

The President of Romania is politically accountable. The simple existence of art. 95 states this. Everything that the President of Romania does in the political field involves political effects and therefore he must express even his political opinions in the respect of his constitutional attributes and limits. Otherwise, he is not a constitutional president and thus he cannot be a guardian of the fundamental law, a social equilibrium factor and a true consensus provider between state authorities.

In the Advisory Opinion on the President's suspension in 2012, the position of the Constitutional Court translates the same pro-presidential subjective attitude.

A fortiori, what can be said about the announcement made by the President, in 2010, about taking, in the name of other public authorities, certain economic measures before they were debated and adopted by the Government in the legal and constitutional procedure?

In connection with these claims, the Court notes that the concrete facts mentioned above, imputed to the President, may take the form of conflicts with other participants in the political life. As for the above mentioned statements of Mr. Traian Băsescu, the Court notes that these can be characterized as political opinions, for which the President of Romania remains politically and morally responsible in front of the electorate and the civil society. Regarding the role of the President of Romania, provided by Art. 80 of the Constitution, the Court finds that Mr. Traian Băsescu did not exercise with maximum efficiency and exigency the function of mediation between the powers of the state, as well as between state and society [20].

We believe that it is quite easy to observe the use of some pro-presidential subjective lenses of judgement when it comes to clarifying the mediator role of the president and that of a guardian of the Constitution. It is worth noting that the RCC is itself a guarantor of the Constitution, a constitutional guardian which established that a visible violation of the Constitution is not a violation taking into account extraconstitutional considerations or circumstances. CCR preferred to adopt a neutral position, leaving constitutional qualifications and judgements to other authorities, e.g. the parliament and, finally, the people.

Interpretations of the Constitution through a pro-president active role lenses can also be found in the following Decisions and judgments relative to the consultative 
referendum and the applicable procedure, e.g. Decision no. 70/1999 [21], Decision 567/2006 [22], Decision no. 147/2007 [23], Decision 355/2007 [24], and Decision no. 33/2009. These Decisions may form the strongest lever of power developed through constitutional justice in the president power prerogatives - the consultative referendum - a unipersonal power tool, autonomous and placed by RCC outside the barriers of checks and balances. Adding the President's opportunity to promote certain messages through diplomatic channels, the consultative referendum may prove to be as powerful as the absolute veto received by Carol I in the fundamental law of 1866, an instrument that irremediably placed the Domn / King in the sphere of effective government, despite the parliamentary desire to put him under the dictum the king reigns but does not govern.

Without doubt, art. 90 of the fundamental law include the rationale of a means of democratic communication between citizens and the head of state, a consequence of the legitimacy that the latter gained through direct election. However, this should not be dismantled and rebuilt in the sense of a power mandate or as an empowerment channel. It should be considered to what extent the constitutional powers of the President can integrate the people in a sort of indirect governance, similar to the parliamentary representation. By such an approach, we understand that the president cannot ask the people to govern through "mediating" against parliamentary representation. However, the CCR did not diminished this danger, but, on the contrary, amplified it, promoting and absolutizing a presidential "right". CCR Decision 799/2011 [25] emphasis yet another presidential autonomy on a conditioned constitutional prerogative. Article 150 of the Constitution sets forth a possibility of constitutional review initiative through the presidential institution, but, nota bene, having as a starting point a revision proposal from the Government. The President's initiative is, thus, conditional and, we believe, lacking autonomous volitional fund. The President, from his position as guardian of the Constitution, is a first filter of constitutional control over the Government's revision draft. If he consents to the Government's proposal, the review procedure continues and the Constitutional Court will, ex officio, judge - intrinsic and extrinsic - the revisions proposed in the draft. Interestingly, the constitutional justice, through the Decision on the constitutional revision draft, above mentioned, established, verifying the conditions for the exercise of the presidential right to initiate constitutional revision, that the President may partially accept the Government's proposal and complement it, as otherwise his initiative right would be emptied of content. We do not agree with this interpretation of the RCC. Embracing the interpretation of the Court, it would mean that Article 150 makes the initiative of the President unnecessarily conditional with the Government's proposal. At the same time, applying the type of reasoning of the Court, it would mean that the Government's proposal could be emptied of content by the President. The logic of the article 
translates the correlation of an initiative that seeks to be consensual between the president and the government. The president cannot have a constitutional review initiative in the absence of the government's proposal and, correlatively, the government's proposal cannot have a final outcome without the President's acceptance. Any presidential disagreements regarding the Government's proposal will have to be overcome by finding a consensus. The President cannot impose his point of view, as it would amount with canceling the proposal from the Government, a sine qua non element for initiating the constitutional review procedure stated in the first thesis of article 150. As such, while maintaining the logic of the constitutional article discussed above, a consultative referendum cannot lead through its outcome to a revision of the fundamental law. Yet, the RCC stated in its judgments that the President has the absolute right to set the object of consultative referendum. For us is unequivocally that the consultative referendum cannot be used in order impose a morally-political impetus for a constitutional review. It would be a pre-legitimation of some possible presidential revision wishes that could be invoked against not only the Government but also the Parliament [26]. The president's prerogative provided by art. 90 must be put into practice in the interest of the people, not for the benefit of a personal political agenda. The use of a referendum on an issue that is only interested by the initiator and introduced populist, propagandistic and demagogically in popular expression does not fit into the parameters of constitutional democracy. The CCR could and should have stated that, but it didn't.

In our attempt to detect how the constitutional justice placed itself against what the founding fathers constitutionally aimed in 1991 with regard to the role and attributions of the President, we may also mention Decision 98/2008 [27], whereby the CCR created the right of the President to reject only once, but motivated, the appointment as minister of the person proposed by the Prime Minister. We can also refer to Decision 683/2012 [28], in which RCC used, outside the constitutional fundamentals, the phrase "considerable attributions" in the president's right, while at the same time acknowledging the right (with priority over Government head the Prime Minister) to represent the Romanian state at the European Council meetings, moving the Government in secondarily place in matters of foreign policy implementation, despite art. 102 par. (1) of the Constitution.

Constitutional justice is important for a coherent constitutional praxis, for the coherence of the democratic-constitutional life, for the activation of what we call the rule of law. Given that a RCC decision validates, in 2007, a referendum on the dismissal of the president with $44,5 \%$ turnout quorum and $74,48 \%$ votes against the dismissal, and another CCR decision, in 2012, invalidates a referendum on the dismissal of the President with $46.24 \%$ turnout quorum and $87.52 \%$ votes in favor 
of dismissal, we can, unfortunately, see the survival, through constitutional justice, of the traditional authoritarian head of state, so strongly blamed in 1991.

\section{Conclusions}

In the post-communist Romania, the desire to break from a non-democratic past did not lead to the extinct of what we call the Romanian tradition of an authoritarian head of state. This is due to mentality, political culture, legal culture and so on. $\mathrm{Al}$ of these generate, somehow in a natural way it seems, authoritarian manifestation of the President, in different political contexts (e.g., consolidated government majority) and through the "help" of the Romanian Constitutional Court. Although the Constitution framework promotes a pattern of a president with limited attributions, conditioned and introduced into a political deployment scheme of a parliamentary regime (or a very quiet semi-presidential regime), something happens [29] and the president manages to keep alive the up mentioned Romanian tradition, and the constitutional justice contributes, as we have seen, to this past conservation.

\section{Notes}

[1] See M. Guțan, Transplant constituțional și constituționalism în România modernă 1802-1866, Edit. Hamangiu, Bucharest, 2013, pp. 360 et. seq., pp. 425 et. seq.; See R.C. Roghină, Transplantul constituțional din 1866, Edit. Universul Juridic, Bucharest, 2016, pp. 260 et. seq., pp. 356 et. seq..

[2] At first, Carol I wanted to give life to the Constitution. The Constitution of 1866 assumed a government in which the monarch only reigned. Carol I, after his first 5 years of reign, noticed the immaturity of the Romanian political class (concentrated on the cultivating only its own interests), therefore he chose to assume an active role in Romania's internal and external policy.

[3] See A. Pencovici, Desbaterile Adunarei constituante de la 1866 asupra constituţiei şsi legii electorale din România, Tipografia Statului, Curtea Şerban Vodă, Bucharest, 1883, p. 80.

[4] In this sense, the Constituent Assembly's debates are eloquent. See, Geneza Constitutiei României 1991. Lucrările Adunării Constituante, Regia Autonomă Monitorul Oficial, 1998, passim.

[5] Ibidem

[6] Decree-Law No. 92/ 1990.

[7] For a Constitutional Transplant debate, see F. Schauer, On the migration of Constitutional ideas, in Connecticut Law Review, Vol. 37, Issue 4, 2005; M. Osiatynski, Paradoxes of Constitutional Borrowing, in International Journal of Constitutional Law, Vol. 1, Issue 2, 2003, pp. 244-268; V. Perju, Constitutional Transplants, Borrowing, and Migrations, in Oxford Handbook of Comparative Constitutional Law, M. Rosenfeld and A. Sajo (eds.), Oxford University Press, Oxford, 2012, pp.1304-1327; R.C. Roghină, 
Transplantul constituțional, in Revista de Drept Public, Nr. 4/2012, Edit. Universul Juridic, Bucharest, pp. 125-140.

[8] The transplant bias concept refers to the situation when a legal system abides a higher receptivity towards a certain legal system, an appropriation which is not based on a critical selection and thus is not taking into account all possible alternatives. This receptivity varies depending on factors such as the source of previous transplants, the linguistic tradition shared with the donor system, the educational influences of the donor system and so on (see A. Watson, Comparative Law and Legal Change, in Cambridge Law Journal, Vol. 37, 1978, nr. 2, pp. 313-336; Idem, Legal Change: Sources of Law and Legal Culture, University of Pennsylvania Law Review, Vol. 131, No. 5, 1982- 1983, pp. 1146-1147). Thus, it can be explained why once again the French societal fund proved attractive, although it did not offer a president model in the role of a simple mediator.

[9] Semipresidentialism, with its many variables, was, in part, an unknown system of governance for the Romanian political and legal fund, so for the Romanian Constituent Assembly also. The recourse to the French constitutional fund does not seem to be, in such circumstances, a random occurrence, given the historical preference for the French legal fund. This highlights what A. Watson calls a biased legal transplant. In particular, the American professor argues that sometimes the performance of norms or legal ideas is not the main reason for carrying out a transplant. In some cases, it may be imposed or due to a bias toward a particular system (legal dependence - transplant bias). Supra footnote no. 8.

[10] M. Guțan, Romanian Tradition in Foreign Law Import: Between Necessity and Weakness, in „Imperialism and Chauvinism in the Law”, colloquium - 20th anniversary of the Swiss Institute of Comparative Law, Schulthess, Genevè - Zurich - Bàle, 2004, pp. 66 et. seq. .

[11] Idem, Forme pe un alt fond: Transplantul Juridic Comunitar si Cultura Juridică Romanească, in Pandectele Romane, Vol. 5/ 2008, p. 19, footnote no. 6.

[12] K.L. Schepelle, Aspirational and Aversive Constitutionalism: The Case for Studying Cross-Cosntitutional Influence Through Negative Models, in International Journal of Constituional Law, vol. 1/2003, pp. 300 si urm..

[13] C. Skach, The „,newest” separation of powers: Semipresidentialism, in International Journal of Constitutional Law, Vol. 5/2007, p. 101. The study is available at: https://academic.oup.com/icon/article/5/1/93/722466/The-newest-separation-of-powers, page accessed on 12.10.2017.

[14] https://www.ccr.ro/files/products/D567_06.pdf, p. 3; https://www.ccr.ro/files/ products/D147_07.pdf ... other RCC Decisions will be mentioned further in the article, regarding the Consultative Referendum.

[15] See RCC Decision 334/2013 https://www.ccr.ro/files/products/D0334_133.pdf vs any Decision regarding the Referendum law, e.g. Decision 567/2006.

[16] Thus, we consider that the Consultative Referendum must not cause, through the will of the president (broadcasted in a manipulated will/voice of the people), changes in the legislative domain.

[17] https://www.ccr.ro/files/products/avizconsultativ.pdf

[18] The RCC pro-presidential subjective interpretation is unequivocally.

[19] https://www.ccr.ro/files/products/Decizie_284_20142.pdf 
"Vasile Goldiș" Western University of Arad

Roghină R.C. (2017)

The Constitutional Court of Romania against the direction of the constitutional moment of 1991

[20] https://www.ccr.ro/files/products/A01.pdf, p. 29

[21] https://www.ccr.ro/files/products/D070_99.pdf

[22] https://www.ccr.ro/files/products/D567_06.pdf

[23] https://www.ccr.ro/files/products/D147_07.pdf

[24] https://www.ccr.ro/files/products/D355_07.pdf

[25] https://www.ccr.ro/files/products/D0799_11.pdf

[26] The Consultative referendum of 2012 and the way CCR judged upon the problematics involved can be a clear example in the sense of highlighting the trend of presidentialising the Romanian political regime.

[27] https://www.ccr.ro/files/products/D098_08.pdf

[28] https://www.ccr.ro/files/products/D0683_12.pdf

[29] E.S. Tănăsescu, The President of Romania or the Slippery-Slope of a Political Regime, în European Constitutional Law Review, nr. 1/2008, p. 69. 